https://helda.helsinki.fi

\title{
At the margins of the Barents energyscape
}

\section{Lempinen, Hanna-Kaisa Elisa}

2018

Lempinen, H-K E 2018 , ' At the margins of the Barents energyscape ' , Barents Studies:

Peoples, Economies and Politics, vol. 5 , no. 1 , pp. 13-34 .<

http://urn.fi/URN:NBN:fi:ula-201810091376 >

http://hdl.handle.net/10138/297677

cc_by

publishedVersion

Downloaded from Helda, University of Helsinki institutional repository.

This is an electronic reprint of the original article.

This reprint may differ from the original in pagination and typographic detail.

Please cite the original version. 


\title{
At the margins of the Barents energyscape
}

\author{
HANNA LEMPINEN
}

Aleksanteri Institute, University of Helsinki, Finland

PO Box 42, 00014 University of Helsinki, Finland

hanna.lempinen@helsinki.fi

$\boldsymbol{y}$

\begin{abstract}
In political, popular, and scholarly debates, the Arctic - and most importantly within it the Barents region - is portrayed as being on the brink of becoming the "world's new energy province". Growth in global energy demand, dwindling reserves, political instabilities at existing production sites, warming climate, as well as advancements in extraction and transportation technologies are pushing energy activities further towards the previously inaccessible north. In these framings, energy in the Arctic is mostly understood as synonymous with oil and gas production for international exports and as a concern of markets and politics, and of technology, science, and economics. Exploring media representations of the regional energyscape through the "theorymethods package" (Clarke 2015, 87) of situational analysis, this article highlights the diversity of regional energy beyond oil and gas production; the simplistic manners in which the societal dimensions of energy are understood; the absence of everyday life, ordinary people, and the female gender from the depictions of the regional energyscape; and the lack of attention to climate impacts of northern energy production.
\end{abstract}

Keywords: Barents; energy; media representations; situational analysis 


\section{INTRODUCTION: PUTTING THE BARENTS REGION ON THE (ENERGY) MAP}

The Barents Region is usually framed as a resource storehouse for global markets (Elenius 2015, 138; Tennberg, Riabova, and Espíritu 2012, 15-18), but as a region it is more diverse. It spans the northern territories of four environmentally, culturally, and politically diverse nation states and it is home to more than five million people of non-indigenous and indigenous backgrounds (BEAC 2016). Politically, the region remains loosely integrated in terms of infrastructure, politics, and regional identity alike (Elenius 2015). However, the increased international interest in the northern regions and the associated strategy work on the regional and state levels has contributed to an increasing emphasis on furthering northern (economic) development (Norwegian Ministry of Foreign Affairs 2014; Prime Minister's Office of Finland 2013; Government Offices of Sweden 2011; Russian Federation Policy for the Arctic 2020). In these envisionings, it is the energy resources in the region that play the crucial role when rethinking its socioeconomic landscape.

In the context of the Barents region and the broader Arctic, the understandings of "energy" in political, popular, and academic debates are "dominated by a focus on oil and gas exploration, development, and extraction" (Sidortsov 2016, 1). This emphasis on the importance of fossil fuel-based energy is by no means surprising, as "the heavy dependence on hydrocarbons" is "a distinguishing feature of advanced industrial societies" (Redclift 2009, 375; see also Salminen and Vadén 2013), and a significant share of the estimated remaining oil and gas resources in the world are located in the seas surrounding the Barents region (cf. USGS 2009). Even though "signs of change in global energy have multiplied" in recent years (IEA 2015a, 12), global energy consumption is still expected to continue to increase substantially, and much of this consumption is still projected to be heavily reliant on fossil fuels (cf. IEA 2015b).

However, framing the Barents region in this manner - as the new oil and gas province for global markets - is a very simplistic view. To begin with, it does not take into account the presence of a variety of renewable energy sources, or coal, peat, and nuclear power in the overall energy landscape of the region (cf. Lempinen and Cambou, forthcoming; Lempinen 2017, 91-92; Banul 2012). In a similar vein, the focus on energy exports ignores the fact that energy is also consumed in the region, which has a cold climate, long distances, and its share of heavy industries: some areas and residents of the Euro-Arctic north are among the highest per capita energy consumers in the world (cf. Rasmussen and Roto 2011, 151). Indeed, some parts of the Barents remain, despite the region's tremendous "energy wealth", 
unevenly characterized by "energy poverty" (Hemsath 2010, 5) and, as such, unable to continuously meet their energy needs in a safe, reliable, and affordable manner (on energy poverty cf. e.g. Bazillian, Nadooka, and Van de Graaf 2014, 219-220; Boardman 1991). The region, its environments, and residents are also vulnerable to the risks associated with the increased shipping of resources (cf. PAME 2009, 136-138) and to the environmental and sociocultural changes brought on by energy project planning and implementation (Kristoffersen and Dale 2014; Wilson Rowe 2016; Bouzarovski and Bassin 2011, 786-787; Stammler and Wilson 2016, 1).

In this article, I seek to go beyond these simplistic hydrocarbon export-dominated understandings of what energy in the Barents region entails. Making use of the "theory-methods package" (Clarke 2015, 87) of situational analysis, the article approaches the regional energy debate as an energyscape and as a situation in the case study context of the media materials of the BarentsObserver news portal. The article focuses 1) on the diversity of constituents that are assembled around the regional energy concern and 2) on who and/or what are left at the margins when the issue of energy in the Barents region is addressed. Through an analysis of the textual and visual representations of energy in the selected media materials, the article highlights i) the diversity of regional energy beyond oil and gas production; ii) the simplistic manners in which the societal dimensions of energy are understood; iii) the absence of everyday life, ordinary people, and the female gender from the depictions of the regional energyscape; and iv) the lack of attention to climate impacts of northern energy production. As such, this article does not explicitly tackle the interests and aspirations of and power relations between different actors or the conditions of production of the analysed materials, but instead delves deeper to the contents and connotations of regional energy representations.

\section{CONSTRUCTING AN ENERGYSCAPE}

Up until this point energy resources have been discussed as if they were just quantifiable and unquestionable states-of-the-world, that is, as if energy and resources were mere "raw materials that can be calculated as barrels, bushels, crates or some other handy units" (Lähde 2015, 60) and that can be assigned an accurate and calculable monetary value (cf. Ferry 2016). However, "resources" should also be understood as a socially and culturally constructed term for the parts of the natural world that are perceived as having utility or value from one perspective or another (Bridge 2009, 1219; also Desbiens 
2013). These "cultural appraisals" (Bridge 2009, 1219) are inherently perspectival and therefore invite discussion on and analysis of "how they are constructed, by whom and for whom" (Nilsson and Filimonova 2013, 3).

Indeed, the instrumental role that energy as a "master resource" (Strauss, Rupp, and Love 2013,11 ) has in making state and everyday functions possible (Rüdiger 2008; Aalto and Westphal 2007; Scrase and Ockwell 2010) means that energy resources "often fall prey to the rhetoric and competing discourses that decision-makers use to sustain, lobby for, and diffuse favored ... policies and services" (Fischhendler, Nathan, and Boymen $2015,114-115)$. This, in turn, has worked to relegate the energy issue to the spheres of markets and high politics and to the domains of (natural) science and technology, with little attention to energy as a soci(et)al concern (cf. e.g. Lempinen 2017; Ciutâ 2010; Newberry 2013, 228). However, I argue that energy is as much a question of cultural and societal practices as it is one of trade, politics, technology, and engineering. The energy concern crosscuts different values, interests, discourses, use(r)s, and living worlds, all of which are considerations far beyond the spheres of institutional politics.

In this article, I build on the understanding that texts and images not only reflect but also shape how the (energy) world and its constituents are thought of and acted upon (Berger and Luckmann 1966). Linguistic representations always highlight some aspects of the same concern while slighting others; visual representations similarly both reflect and construct the ways in we which see, experience, and enact the world (cf. Seppänen 2005, 78; Rose 2007, 12). The presence of an image in any given body of text is always the result of a choice, either intentional or unconscious. In a similar manner, the choices made in constructing the texts and images are always shaped by cultural practices and questions of power and politics (Rose 2007, 26), just like the words we use. This applies also to media representations - despite their seeming neutrality and objectivity (cf. Kunelius 2009; McCombs 2005; Goffman 1974)

These uses and abuses of energy language are intrinsically entangled with power (Scrase and Ockwell 2010; Fairclough 1989; Lakoff and Johnson 1980). As a consequence, any discussion or concern related to energy is profoundly intertwined with the questions of politics and the political (cf. Palonen 1983). Viewing the (energy) political as being shaped by and taking place through language, linguistic choices, and framings (cf. e.g. Sengers, Raven, and van Venrooij 2010; Hajer 1995) highlights both the profoundly discursive nature of energy-related policymaking and the diverse range of actors potentially involved in energy-related developments and debates. The ways in which things - including energy 
- are discussed and defined are neither innocent nor without potential consequences: "different views of energy shape policy choices, which in turn further legitimise particular views", and "[t]he effects of policy decisions based on particular views can be profound" (Mason 2016, 132). For this reason, it is important to critically investigate the ways in which northern energyscapes are represented (see also Sidortsov 2016).

As the inherently political nature of energy-related language use has been broadly acknowledged, the ways in which linguistic choices play out in shaping our understandings and actions in relation to energy have been investigated on several fronts. Extensive work has been conducted on, among other topics, strategies and patterns of energy argumentation (e.g. Littlefield 2013; Corvellec 2007; Windisch 2008), discourses on and the framing of different energy sources and alternatives (e.g. Scrase and Ockwell 2010; Sengers, Raven and Van Venrooij 2010), as well as verbal and visual energy metaphors and rhetoric (Lempinen 2013; Anshelm 2008; Littlefield 2013; Fitzgerald 2012; Livesey 2002; Mason 2016; Tynkkynen 2016). However, I argue that there remains a gap in the ways in which the discursivity of energy-related concerns is addressed, as to date few studies have attempted to go beyond the framings of dominant actors, hegemonic discourses, or linguistic representations of individual energy sources or single issues or phenomena. The aim of this study is rather the contrary: to draw attention to the diversities and multiplicities of the elements that together, as a whole, constitute and contribute to the regional energyscape, with an eye to what might be lurking in the margins of the depictions of the world's new "energy province" (Hemsath $2010,12)$ in the selected empirical materials

In this article, this complexity of the regional energy concern is open-endedly approached and addressed through the notion of energyscape (see also Strauss, Rupp, and Love 2013; Kaisti and Käkönen 2012; for "scapes" see Appadurai 1996). As a concept, "energyscape" draws attention to the ways in which a diversity of different elements relate to and come together around energy in a given space and place (cf. Neumann and Neumann 2015, 799). Building on the notion of energyscape also implies understanding the regional concern as a situation: a setting within which everything "both constitutes and affects most everything else in the situation in some way(s)" (Clarke, 2005, 72, italics in original). The key to such an approach is its focusing on the diversity of issues, entities, and discourses that together constitute the regional energy situation in the body of empirical materials - without assumptions about who or what matters in relation to energy, and without a pre-existing interest in who might matter most. 
When approached through the conceptual prism of the energyscape, energy is not automatically relegated to the arenas of state politics and market operations or wholly outside everyday life, and experience: while it is an object of high-level decision-making and corporate activities, it is also a "cultural artifact" that manifests itself differently in different temporal and spatial settings and at different scales (Strauss, Rupp, and Love 2013, 10-11). Energy permeates societies, technologies, and economies as well as ways of communicating, thinking, and living far beyond institutional politics or market transactions. It is exactly this diversity that the notion of energyscape has the conceptual potential to capture; however, no amount of conceptual readiness can translate into being able to grasp those issues and perspectives that might be lacking from the "realworld" discussions and debates.

\section{METHODS AND MATERIALS}

In order to accommodate the viewpoints above, the Barents energyscape is approached here through the "theory-method package" (Clarke 2005, 4) of situational analysis (SA). As the name implies, SA takes the notion of situation as both the starting point and the locus of analysis. The aim of SA-oriented research is to gain a comprehensive understanding of "the full situation" (ibid., xxvii) under investigation in the empirical materials utilized. Analyses in this vein undertake to map and lay out as comprehensively as possible the diversity of entities and elements - equally human, nonhuman, discursive, and ideational - through and among which the situation exists and is constructed in the context of the empirical case study. Another specific interest is what might be missing from the representations of the regional energyscape - who or what is physically "there", but has been left out of its discursive representations (cf. Salazar Pérez and Cannella 2013, 512). Indeed, an SA-oriented research setting acknowledges that "there is always some prior knowledge to direct the gaze of the researcher" (Clarke 2005, 28-29; also Charmaz 2000). In this study, such prior knowledge translates into explicitly paying attention to themes and elements that might be left at the margins of or outside the political and popular energy-related debates.

While situational analysis is only gradually becoming institutionalized as a method of inquiry alongside the more "established" approaches to textual analysis, a growing body of research has demonstrated SA's applicability in analysing the diversity and complexity of energy as a societal concern (cf. e.g. Fitzgerald 2012; Tennberg and Vola 
2013; Tennberg and Lempinen 2015). Owing to its focus on "situation" as a whole, SA also provides a tool for overcoming the limitations of more institutionalized approaches to energy-related language use. Instead of providing fragmented perspectives to the energy debate through analyses of dominant actors, hegemonic discourses, and the language of energy persuasion, SA-oriented analysis seeks to grasp the complex intertwinements of energy and the society at large. Energy becomes both an ordering perspective on a given situation and constitutive of the same broader societal context, as it is itself ordered by the other elements, events, and developments in the same situation and/or in the same set of materials.

In its textbook applications, situational analysis proceeds through and visually highlights the "content" or constituents of a situation through the process of mapping (Clarke 2003, 2005,2010 ), making note of the diversity of issues and themes that together comprise the regional energy concern. The outcome of the mapping process, the situational map, is a visual representation of "all the actors and discourses in the situation regardless of their power" (Clarke, Friese, and Washburn 2015, 16; italics in original). The situational map of the Barents energyscape presented in the following section thus lays out the elements that are connected, in one way or another, with the developments, debates, and policies relating to the issue of energy in the analysed empirical materials during the period under investigation. However, as the relations change and elements and events emerge and disappear over time, the map should not in any respect be taken to represent "locations" of different elements or their relative distance from each other or the energy concern. The dynamic not captured in the seemingly static image, that is, the manifold and changing relations and framings of different concerns and elements, is discussed in more detail in textual form in the sections following the map in the empirical analysis below.

The empirical materials utilized in this study were gathered from the BarentsObserver, an online news service with a focus on reporting on and from the Barents region with an aim to promote "political, business and people-to-people contacts across the borders in the region" (BarentsObserver 2014). The portal that was run by the Norwegian Barents Secretariat and financed by the three northernmost counties of Norway was active in 2002-2015, but as a consequence of disputes over the scope of the portal and principles of editorial freedom, the news service now only exists as a news archive (for a summary cf. e.g. BarentsObserver 14 October 2015). The Observer was selected as the empirical material of this article owing to 1) their dedicated section for regional energy-related reporting and 2) the media practice of citing a broad range of sources in producing 
news items: they bring together a wide array of actors, documents, policies, voices, and interests into one coherent and accessible dataset.

In practice, the materials were retrieved from the news portal using two methods. First, all 936 entries classified under the section "Energy" were taken into account. Secondly, also a keyword search using the term "energy" was conducted, after which a total of 511 additional news articles were added to the research materials. The images of the news entries were also included in the analysis to strengthen, complement, and challenge the observations made on the textual contents along the principles of data triangulation (for triangulation see e.g. Rothbauer 2008, Bryman 2004). As a result, a total of 1447 entries dated between 19 February 2008 and 31 July 2014 were analysed, the latter being the date on which all existing entries were retrieved from the database. Overall, the articles were written during an era characterized by rising and/or high oil prices (cf. OPEC 2016, 91), but one yet to feel the full impacts of sanctions and cooling international relations in the aftermath of the Ukraine crisis (for an overview cf. European Union Newsroom 2016). This was the period of high expectations for the future of the Barents as the world's new energy province.

The extensive empirical materials were analysed manually by going through the entries repeatedly to identify the elements in whose interplay the energyscape is assembled and constructed: to lay out what elements and entities are entwined with energy in the empirical materials. While the total number of news entries was quite high, the entries focused on and followed the course of a limited number of developments and megaprojects, which meant that the same issues, themes, events, and also images recurred throughout the period investigated. In the first phase of analysis, the observations based on the textual materials of news entries were compiled onto the situational map presented below. In the second phase, the images of the news entries were analysed with a focus on the "visual identity" (Wright 2011, 311) that the images construct for the Barents energyscape. As such, the process of analysis relied on a rather loose interpretation of the principles of SA, but remained faithful to its core principles of data orientation; focus on situations as a whole; attention to diversity and heterogeneity; and the aim of creating a detailed understanding of the situation instead of universal theory generation (cf. Clarke 2005). In the empirical section below, the news entries are cited by their publication date in the form DD.MM.YYYY.

An inquiry making use of media materials inevitably raises issues that need to be addressed. A major concern is that despite its seeming objectivity media content cannot 
be perceived as offering objective representations of the (energy) world any more than other linguistic representations can. Media representations are always formed in the interplay of (un)conscious interests, choices, and practices of media production and consumption, and the limitations set by media economics (cf. Cunningham, Flew, and Smith 2015; Bräucher and Postill 2010; Wright 2011, 333; McCombs 2005; Goffman 1974). Media representations themselves are still worthy of analysis in their own right: regardless of whether the choices at work in these processes are intentional or not, the ways in which different entities and elements are portrayed take part in constructing and advocating their own kind of view to the world.

\section{REMAPPING THE BARENTS ENERGYSCAPE}

In order to begin to grasp the sidelined, overlooked, and marginalized themes and perspectives of the regional energy concern, we need first a comprehensive understanding of how the Barents energyscape as a whole is depicted. The situational map on the next page condenses "the situation of inquiry broadly conceived" (Clarke 2005, xxii) - all the different elements and entities that together comprise the regional energy concern as it is constructed in the extensive news entries that form the empirical core of this study. It merits pointing out that as a key motivation of both this research endeavour and situational analysis lies in capturing the elements and aspects sidelined and overridden by dominant perspectives, the presence of an element in the situational map does not signal equal weight, equal importance, or an equal share of attention devoted to it in the original research materials. However, its presence on the map serves to highlight that it is indeed "there" and a weighty part of the regional energyscape, even if it were a marginal(ized) one.

Before moving on to the issues and concerns that might be sidelined or left at the margins of the regional energy debate, the energyscape as a whole needs to be briefly opened up and discussed. The situational map above gives an impression of the regional energy concern much broader than the storyline of oil and gas exports. In addition to the allegedly abundant oil and gas resources, other hydrocarbons still contribute to the regional energy puzzle: this is the case not only for coal, which continues to be produced in, transported from, and consumed in the region (e.g. 19.8.2010, 22.2.2012, 27.3.2014), as does peat (5.11.2011). However, it is not coal or peat but the diverse renewable energy resources in all their various forms - wind, hydro, tidal, wave, solar, and biomass - that receive the bulk of the non-hydrocarbon attention in the media materials analysed (cf. e.g. 5.12.2013, 7.5.2013, 13.1.2014, 5.6.2009, 10.2.2009, 6.2.2009). In addition, nuclear 


\section{Energy efficiency}

Energy saving

CSS

$\varnothing$

\section{OIL AND GAS}

\section{Col}

Peat Wind Hydro

Solar Biomass

Tidal Wave 
Nudear

\section{Electricity}

Heatina

\section{Local use}

Production

Exports

Consumption 
power - a prominent impetus for political cooperation in the Barents region (cf. BEAC 1993) - remains firmly on the regional energy agenda (cf. e.g. 16.12.2010, 27.1.2011, $22.11 .2013,12.2 .2010,24.2 .2011)$. The situational map also highlights that energy is consumed in the region in significant quantities (e.g. 4.11.2013, 5.9.2013, 26.5.2009, 22.2.2011, 5.9.2013, 29.8.2008, 22.7.2009). What is more, limiting the consumption of energy is taken up: entries are found calling for, advocating, and formulating energy efficiency and saving measures in the energy industry and others alike (cf. e.g. 4.7.2009, 30.5.2011, 12.5.2009, 20.4.2009; also Hirvaskari and Geraschenko 2015).

As a whole, the Barents energyscape depicted by the regional energy reporting is without doubt one of "great expectations" (16.1.2012). The region's waters "could hide oil and gas resources of elephant proportions" (8.11.2013). Indeed, the regional energy developments are depicted as something unprecedented in magnitude: projects that are unfolding in the cold and icy waters of the northern seas are portrayed as series of "first evers" (cf. e.g. 7.5.2014, 8.4.2014, 6.12.2012, 30.11.2010): as the "northernmost in the world ever" (8.5.2014, also 10.3.2010, 7.7.2008, 29.8.2012) but nevertheless as being realized within a "time frame that is unprecedented" (28.8.2013). Energy technologies and developments are compared to the "moon landing" (20.1.2011) and the "conquering of the cosmos" (26.5.2011). Together, these narratives construct northern energy development as "a heroic endeavor in which ordinary men could participate and thus become larger than life" (Desbiens 2013, 134; italics mine). Yet, there also challenges for the bright energy future. A crucial one is a lack of knowledge: the visions of the bountiful resources of the region are based on estimates only, and it might be shown that the estimates of the quantity of resources have been overly optimistic and unrealistic from the outset (e.g. 10.4.2014, 31.8.2010, 5.10.2012, 7.9.2011; see also Lähde 2015). The environmental and climatic conditions also "get increasingly tough as the oil industry moves further north into Arctic waters" (31.10.2011), making operations riskier both in the physical and financial sense (cf. also Emmerson and Lahn 2012). As a consequence, the Barents energyscape is not only one of high hopes but also of disappointments and delays (23.10.2013, 2.1.2014, for summary from 2012 cf. 3.10.2012).

In addition to the tensions between harsh realities and high expectations, the situational map of the Barents energyscape also showcases the "heterogeneous assemblage of different actors" (Kaisti and Käkönen 2012, 148) that come together around the boundary object of the regional energy concern. Indeed, also Clarke, Friese, and Washburn $(2015,18)$ emphasize the potential that the framework has for identifying and addressing the variety of "stakeholders", actors, and institutions potentially 
affected by but not recognized in the processes of policymaking. While differences can be found between the political and administrative systems in the region (cf. Glomsrød and Aslaksen 2008, 17-22), in the overall Barents energyscape equally states within and outside the region, national and global energy corporations, supporting industries, regional actors, international organizations, and institutions all have a role to play in the formation of the regional energy concern (cf. e.g. 21.11.2013, 18.6.2012, 14.7.2009, 29.6.2012, 25.9.2012, 31.7.2008, 10.12.2010, 2.8.2012; also Aalto et al. 2013). Furthermore, through its reporting - the decisions regarding what to report on and how - the news service BarentsObserver itself does much to promote a certain kind of understanding of the regional energyscape over others.

The relationships between these different actors are, however, in constant change and far from unproblematic. The energyscape of the region is fraught with tensions and polarized along the axis from cooperation to conflict (e.g. 24.11.2011, 25.3.2011, 30.9.2008, 10.7.2008, 3.3.2011). The messy nature of the positions taken and the relations formed renders the often-presented "cooperation or conflict" configuration used to describe the nature of the energy concern quite absurd, as both extremes can and do exist in the same energy situation, which, in turn, appears very different depending on the perspectives and actors involved.

The discussion on who acts and matters in relation to the regional energy debate is intimately linked to energy being at the same time a very regional and a thoroughly global concern. The Barents energyscape is not only "inhabited" and moulded by state and corporate actors and institutions originating far away from the region (e.g. 21.8.2012, 7.6.2008, 10.12.2010, 24.2.2009), but also dependent on global market fluctuations $(3.6 .2010,13.5 .2009$, (24.10.2012), international political tensions and events $(22.9 .2008,20.8 .2008,20.1 .2010,6.11 .2008)$, as well as incidents such as the Gulf of Mexico spill and the Fukushima disaster (cf. 20.1.2010, 6.11.2008, 16.3.2011). The energy concern in the Barents region is also a profoundly regional one. Energy developments taking place in the region have been reserved an instrumental role in turning around the patterns of depopulation and economic decline plaguing the northern towns, counties, and municipalities. These developments are expected to contribute to improved infrastructure $(28.6 .2014,1.12 .2008)$, create incentives for training and education (26.1.2009, 9.7.2008), and bring tax revenues, employment, and increased income (12.6.2013, 27.1.2012, 5.6.2011, 1.7.2014). In sum, they mean "taxes, roads, employment, expertise" (28.9.2012; italics mine): “200,000, 300,000 and probably even 400,000 jobs" (15.4.2012) to the otherwise economically challenged region. 


\section{EXPLORING THE MARGINS}

The news entries portray and construct the thoroughly transnational regional energyscape in terms of great expectations for northern energy development and their beneficial "spin-offs" (12.7.2012, 7.4.2011) and "ripple effects" (27.2.2013) for regional (economic) development. However, in the light of the primary concern of this work, the most interesting observations may very well be what is not among the main themes and topics in terms of which the regional energy concern is framed in the Observer materials. The lack of attention to any societal concerns beyond regional socioeconomics is among the most evident "absences" (Clarke 2015, 105) in the regional energyscape. Despite the widely acknowledged "growing criticism of cultural ignorance with which many energy implementation projects are handled" (Bastholm and Henning 2014, 1; also Mitchell et al. 2001), the 1447 news entries of energy talk succeed to a great extent in evading any explicit and extensive attention to the social dimension associated with energy in the region. Beyond references to (symbolic) practices of public participation and protest (4.2.2011, 5.3.2010, 3.3.2010, 17.4.2012, 13.7.2010, 27.4.2010), the presence of other local livelihoods (e.g. 3.2.2013, 29.6.2012, 4.2.2011, 4.10.2010, 21.10.2008, 5.6.3013), and abstract references to "value creation" (30.6.2008), corporate social responsibility (25.5.2012), "social development" (7.11.2008), and "social infrastructure" (22.10.2008), the soci(et)al dimension of energy, communities, and societies is not really "there". The amount of presence assigned to local residents or populations is scanty. They are practically never directly cited and are thus not given a voice of their own - not even in the coverage of a news service deeply rooted in promoting "peopleto-people cooperation" in the region (cf. BarentsObserver 2014). As a whole, these findings echo the observations about the simplistic views to the "social" made in the context of broader Arctic energy debates (cf. Lempinen 2017).

Indeed, particularly striking are the ways in which the hopes for a better future are so closely intertwined with the expectations tied to regional energy development. Especially the region's hydrocarbon energy resource endowments continue to be consistently framed in developmental terms: as the developmental strategy of Arctic communities and societies whose existence, well-being, and development "hinges on being able to capture the value and benefits of their natural resources" (Bertelsen, Justinussen, and Smits 2015, 22). Curiously enough, this remains the case even in a situation where previous experiences have repeatedly demonstrated "that societies cannot necessarily rely on extractive industries as a secure foundation for future development" (Stammler and Wilson 2016, 3). However, the finite nature of hydrocarbon resources is not accounted for when the building blocks of the regional energy future are assembled. The timeframe of the Barents energyscape and 
development within it does not extend to a "post-petroleum" era, when there is no more oil and gas left to produce (cf. Kristoffersen and Dale 2014).

At the same time as energy in the north appears to be entangled in more or less all major challenges and developments that are unfolding in the region, there is one grand concern to which surprisingly little attention is devoted within the explicit framework of energy: climate change. While recent studies have pointed out the incompatibility between internationally agreed limits to global warming and Arctic hydrocarbon production (McGlade and Ekins 2015), in the energy-related reporting the climate obstacle becomes framed mainly as an additional technological challenge posed by the requirements for CO2 capture and storage (24.4.2008, 27.7.2009, 10.3.2010). Very little visibility is accorded to the justifications for or necessity of hydrocarbon development. Scattered references to statements from the Church of Norway, the EU Parliament Environmental Committee, and environmental organizations (19.2.2009, 3.10.2012, 6.8.2012) are the only instances where news items engage in the ethical side of the climate debate. This ominous silence (cf. also Norgaard 2011; Tynkkynen and Tynkkynen, forthcoming), accompanied as it is by references to the role of $\mathrm{CO} 2$ capture and storage technologies and capping of climate gas emissions, implicitly ties the idea(l)s of northern energy developments to those of ecological modernization (cf. Hajer 1995), elevating technology to a force reconciling the contradictions between the socio-environment and large-scale, CO2-intensive "development".

\section{IMAGIN(IN)G THE ENERGYSCAPE}

In general, visual elements can illustrate and underline the content of a written text as readily as they may challenge and augment it (Seppänen and Väliverronen 2002; Van Leeuwen 2011, 51; Rose 2007, 11). As such, the images of the news entries offer an additional fruitful avenue for investigating how the Barents energyscape is conveyed and constructed. In this section, I mainly focus on how visual materials add to, complement, or challenge the manners in which the energyscape is textually represented, with less attention to where the images only visually underline the textual content and thus serve mainly an illustrative role (cf. Van Leeuwen 2011, 551).

In the context of visually representing energy, the images of the news entries predominantly echo the prominent role assigned to hydrocarbon and energy exports in the textual materials of the news entries. However, the visuals of energy also add to the verbal storylines. A considerable amount of energy-related imagery focuses on 
portraying energy as oil rigs defying the vast open Arctic seas' energy (e.g. 14.10.2014, 26.11.2014, 10.9.2014, 16.4.2015), even though the actual number of offshore installations in operation in the region remains at best modest. In a similar manner, illustrations of project implementation plans make into being an energyscape which to a large extent still only exists on the level of political speeches, corporate strategies, and engineering agencies (cf. e.g. 16.9.2009, 8.1.2010, 14.9.2010, 3.7.2013). Together, the iconic oil rigs, project maps, and illustrations render visible an energy province that is only yet to come: amid the disappointments, delays, and declining economies it is possible that the value of "the drama and the character of today's images of the energy future lie[s] in their capacity for governing over the decay of the present" (Mason 2006, 4).

The images of the news entries echo the textual representations also in their focus on political and market actors: amidst all the images of presidents, ministers, and company CEOs, images of flags and corporate logos only further underline the importance of states and markets as actors in the Barents energyscape (e.g. 15.9.2008, 3.5.2011, 8.12.2009, 12.10.2009, 15.3.2011, 25.3.2011). Together, the images construct an understanding of the regional energy concern that has very much to do with state authorities and high-level politicians and very little to do with everyday life and existence in the region. Indeed, it is a striking feature of the news images that "ordinary" people seem to have all but disappeared from the regional energyscape. Among the very few are photographs of indigenous reindeer herders (8.10.2009) or people driving their cars on the snowy northern streets (7.12.2010). However, while "life" in the energyscape is not portrayed or visualized, working life in the energy industry is. Countless and countless images represent people at work at the energy installations in the region, wearing their company overalls (e.g. 26.6.2009, 31.10.2011, 1.7.2013, 4.4.2014, 6.8.2014, 26.11.2011). The ways in which the humans in the energyscape are portrayed leave little room for interpretation in terms of the roles assigned to the people living in the region. The mantra-like verbal discourse on employment and income is echoed and accentuated by the visual illustrations of the energy debate.

What is more, the images of male workers at energy installations also hint at whose employment and income it is that is at stake in northern energy development. There is indeed one other rather crucial question to be asked and answered with regard to who is present and represented in the Barents energyscape: What is the one quality or attribute shared by the vast majority of the politicians, corporate leaders, researchers, and the bluecollar workers in the images? The answer is: their gender is male. The Barents energyscape is not only an issue of high politics, international markets, and regional socioeconomics 
but also, more often than not, a blatantly, unashamedly masculine one (cf. also Desbiens 2013, 59; Tynkkynen 2016, 387). Through the repeated inclusions and exclusions (cf. Rose 2007,12 ), or choices of whom to picture and whom not to, the images swiftly sideline the female gender to the margins of the regional energyscape - and beyond.

\section{CONCLUDING THOUGHTS}

In this article, a set of media representations of the Barents energyscape has been scrutinized with an aim not only to investigate the themes and terms by which the regional energy concern is constructed, but also to highlight issues and perspectives that may be left out or in the margins of the debates revolving around energy in the north. In this endeavour, situational analysis of texts and images together with situational mapping have proven highly useful: a more detailed reading of the regional energy debate showcases a more nuanced understanding of the regional energy concern compared to understanding northern energy solely as exports of oil and gas. However, while renewable and other energy sources as well as energy consumption, efficiency, and saving are increasingly being carved space on the Barents energy agenda, it is the large-scale oil and gas projects and the unforeseen benefits they are expected to bring to regional economic development that continue to dominate the regional energy imagination.

The situational map of the Barents energyscape has laid out a stunningly diverse range of issues that are intertwined with the regional energy concern in the region. In combination with an analysis of the images of the news entries, it has also served to highlight some of the issues and perspectives that remain sidelined from the regional energy-related debates. Among them, the non-existent presence of any societal aspects or everyday life concerns is potentially the most astounding observation: even in the materials of a regional news source, the intertwinements of energy with "personal and professional growth, family relations, work-life balance, and other quality-of-life topics" (Sørnes, Browning, and Henriksen 2015, 3) are not addressed, leaving the soci(et)al aspects of energy reduced to regional socioeconomic concerns. Equally disturbing are the gendered visual representations of energy in the context of the north, when male workers become the (only) visual embodiment of the interrelations of regional energy development and ordinary people and everyday life. These images tell their own tale of whose jobs, income, and lives the regional energy developments are about. These observations are not meaningless, because the ways in which the energyscape is depicted contributes to a certain kind of understanding of energy in the north: why and for whom energy "matters" and who is taken into account when the "world's new energy province" is constructed. 
As a whole, the iconic images of drilling installations standing alone in the vast emptiness of Arctic landscapes portray an energy future that is yet to come: it is one of large-scale offshore production and of a new "cultural relationship to the land that unfolds within the paradigm of progress, productivity and triumphant modernity" (Desbiens 2013, 39). What is more, such "triumphant modernity" takes very little account of the climate impacts of northern energy production. This silence or denial around the climate concern in the context of energy appears especially odd when it is seen against the background of accelerating natural and social change in Arctic the region. While climate change is widely accepted as one of the major threats to sustaining societal and cultural well-being and human development in the circumpolar north (cf. e.g. Nymand Larsen and Fondahl 2015), the climate impacts of Barents energy developments are overlooked. Paradoxically, the future development prospects of northern societies are framed as dependent on the very same oil and gas developments which will eventually only further feed the greatest threat faced by the societies of the north: climate change.

\section{REFERENCES}

Aalto, P., Dusseault, D., Kennedy, M. D., and Kivinen, M., 2013. Russia's energy relations in Europe and the Far East: Towards a social structurationist model of energy policy formation. Journal of International Relations and Development, 17, 1, pp. 11-29.

Aalto, P. and Westphal, K., 2007. Introduction. In: P. Aalto, ed., EU-Russian energy dialogue: Europe's future energy security. Aldershot: Ashgate, pp. 1-21.

Anshelm, J., 2010. Among demons and wizards: The nuclear discourse in Sweden and the reenchantment of the world. Bulletin of Science, Technology and Society, 30, 1, pp. 43-53.

Appadurai, A., 1996. Modernity at large: Cultural dimensions of globalization. Minnesota: Minnesota University Press.

Banul, K., 2012. Mapping renewable energy policies in the Barents region from a multi-level governance perspective. In: M. Tennberg., ed., Politics of development in the Barents Region, Rovaniemi: Lapland University Press, pp. 265-297.
BarentsObserver, 2014. About: News from the Barents region. Available at: http://barentsobserver. com/en/news-barents-region (Accessed 10 September 2017).

Bastholm, C. and Henning A., 2014. The use of three perspectives to make energy implementation studies more culturally informed. Energy, Sustainability and Society, 4, 3, pp. 1-14.

Bazilian, M., Nakhooda, S., and Van de Graaf, T., 2015. Energy governance and poverty. Energy Research \& Social Science, 1, pp. 217-225.

BEAC, 2016. The Barents region. Available at: http:// www.beac.st/en/About/Barents-region (Accessed 4 March 2016).

BEAC, 1993. Kirkenes Declaration. Available at: https://www.barentsinfo.fi/beac/docs/459_doc_ KirkenesDeclaration.pdf (Accessed 31 January 2016).

Berger, P. L. and Luckmann, T. (1966). The social construction of reality: A treatise in the sociology of 
knowledge. Garden City: Anchor Books.

Bertelsen, R., Justinussen J. C., Smits, C., 2015.

Energy as a developmental strategy. Creating knowledge-based energy sectors in Iceland, the Faroe Islands and Greenland. In L. C. Jensen and G. Hønneland, eds., Handbook of the politics of the Arctic. Cheltenham: Edward Elgar, pp. 3-25.

Boardman, B., 1991. Fuel poverty. London: Belhaven Press.

Bouzarovski, S. and Bassin. M., 2011. Energy and identity: Imagining Russia as a hydrocarbon superpower. Annals of the Association of American Geographers, 101, 4, pp. 783-794.

Bräucher, B. and Postill, J., eds., 2009. Theorising media and practice. New York: Berghahn.

Bridge, G., 2009. Material worlds: Natural resources, resource geography and the material economy. Geography Compass, 3, 3, pp. 1217-1244.

Bryman, A., 2004. Triangulation. In: M. S. LewisBeck, S. Michael, A. Bryman, and T. F. Liao, eds., The SAGE encyclopedia of social science research methods. Thousand Oaks: Sage, p. 1143.

Charmaz, K., 2000. Grounded theory. Constructivist and objectivist methods. In: N. K. Denzin and Y. S. Lincoln, eds., Handbook of qualitative research. Thousand Oaks: Sage, pp. 509-535.

Ciutâ, F., 2010. Conceptual notes on energy security: Total or banal security? Security Dialogue, 41, 2, pp. 123-144.

Clarke, A. E., 2015. From grounded theory to situational analysis: What's new? Why? How? In: A. E. Clarke, C. Friese, and R. Washburn, eds., Situational analysis in practice: Mapping research with grounded theory. Walnut Creek: Left Coast Press, pp. 84-118.

Clarke, A. E., C. Friese, and R. Washburn, 2015. Introduction to situational analysis. In: A. E. Clarke, C. Friese, and R. Washburn, eds., Situational analysis in practice: Mapping research with grounded theory. Walnut Creek: Left Coast Press, pp. 11-75.

Clarke, A. E., 2010. Situational analysis. In: A. J. Mills, G. Durepos, and E. Wiebe, eds., Encyclopedia of case study research. Thousand Oaks: Sage, pp. 871-875.
Clarke, A. E., 2005. Situational analysis: Grounded theory after the postmodern turn. Thousand Oaks: Sage.

Clarke, A. E., 2003. Situational analyses: Grounded theory mapping after the postmodern turn. Symbolic Interactionism, 26, 4, pp. 553-576.

Corvellec, H., 2007. Arguing for a license to operate: The case of Swedish wind power industry. Corporate Communications: An International Journal, 12, 2, pp. 129-144.

Cunningham, S., Flew, T., and Swift, A., 2015. Media economics. London: Palgrave Macmillan.

Desbiens, C., 2013. Power from the north: Territory, identity, and the culture of hydroelectricity in Quebec. Vancouver: University of British Columbia Press.

Elenius, L., ed., 2015. The Barents region: A transnational history of subarctic Europe. Oslo: Pax.

Emmerson, C. and Lahn, G., 2012. Arctic opening: Opportunity and risk in the High North. Chatham House-Lloyd's Risk Insight Report. Available at: https://www.chathamhouse.org/publications/papers/ view/182839 (Accessed 16 June 2014).

European Union Newsroom, 2016. Highlights: EU sanctions against Russia over Ukraine crisis. Available at: https://europa.eu/newsroom/highlights/ specialcoverage/eu_sanctions_en? (Accessed 12 June 2016).

Fairclough, N., 1989. Language and power. London: Longman.

Ferry, E., 2016. Gold prices as material-social actors: The case of the London gold fix. The Extractive Industries and Society, 3, pp. 82-85.

Fischhendler, I., Nathan, D., and Boymel, D., 2015. Marketing renewable energy through geopolitics: Solar farms in Israel. Global Environmental Politics, 15, 2, pp. 98-120.

Fitzgerald, J., 2012. The messy politics of "clean coal": The shaping of a contested term in Appalachia's energy debate. Organization \& Environment, 25, pp. 437-451.

Glomsrød, S. and Aslaksen I., eds., 2008. Economy of the north II. Oslo: Statistics Norway.

Goffman, E., 1974. Frame analysis: An essay on the 
organization of experience. Cambridge, MA: Harvard University Press.

Government Offices of Sweden, 2011. Sweden's strategy for the Arctic region. Available at: http://www. government.se/content/1/c6/16/78/59/3baa039d.pdf (Accessed 24 November 2014).

Hajer, M., 1995. The politics of environmental discourse: Ecological modernization and the policy process. Oxford: Oxford University Press.

Hemsath, J., ed., 2010. Arctic energy summit: Final report and technical proceedings. Anchorage: The Institute of the North.

Hirvaskari M. and Gerashchenko I., eds., 2015. Multidisciplinary approach to developing energy efficiency in the Barents region. Publication series B reports 12/2015. Rovaniemi: Lapland University of Applied Sciences.

IEA, 2015a. World energy outlook 2015: Executive summary. Paris: International Energy Agency.

IEA, 2015b. Energy and climate change: World energy outlook special report. Available at: https://www. iea.org/publications/freepublications/publication/ WEO2015SpecialReportonEnergyandClimateChange. pdf (Accessed 20 September 2017).

Kaisti, H. and Käkönen, M., 2012. Actors, interests and forces shaping the energyscape of the Mekong region. Forum for Development Studies, 39, 2, pp. 147-158.

Kristoffersen, B. and Dale, B., 2014. Post petroleum security in Lofoten: How identity matters. Arctic Review on Law and Politics, 5, 2, pp. 201-226.

Kunelius, R. 2003. Viestinnän vallassa: Johdatus joukkoviestinnän kysymyksiin. [An introduction to questions in mass communication] Helsinki: WSOY.

Lempinen, H. and Cambou, D., forthcoming. Energy security in the Barents region: A focus on societal perspectives. In: K. Hossain and D. Cambou, eds., Societal security in the Arctic-Barents region: Environmental sustainability and human security. London: Routledge.

Lakoff, G. and Johnson, M., 1980. Metaphors we live by. Chicago: Chicago University Press.

Lempinen, H., 2017. The elusive social: Remapping the soci(et)al in the Arctic energyscape. Lapland University Press.
Lempinen, H., 2013. “Jos se ei riitä, siitä riidellään”: energiaturvallisuuden kieli ja kuvakieli turve-energian markkina-argumentteina. [What is scarce will be fought for: Visual and verbal representations of energy security supporting a pro-peat energy worldview]. Alue ja ympäristö, 42, 2, pp. 53-63.

Littlefield, S. R., 2013. Security, independence and sustainability: Imprecise language and the manipulation of energy policy in the United States. Energy Policy, 52, 1, pp. 779-788.

Livesey, S. M., 2002. Global warming wars: Rhetorical and discourse analytic approaches to Exxonmobil's corporate public discourse. Journal of Business Communication, 39, 1, pp. 117-146.

Lähde, V., 2015. Politics in a world of scarcity. In K. Bergnäs, T. Eskelinen, J. Perkiö, and R. Warlenius, eds., The politics of ecosocialism: Transforming Welfare. Oxon: Routledge, pp. 55-67.

Mason, A., 2006. Images of the energy future. Environmental Research Letters, 1, pp. 1-4.

Mason, A., 2016. Arctic energy image: Hydrocarbon aesthetics of progress and form. Polar Geography, 39, 2, 130-143.

McCombs, M., (2005). A look at agenda-setting: Past, present and future. Journalism Studies, 6, 4, 543-557.

McGlade, C. and Ekins, P., 2015. The geographical distribution of fossil fuels unused when limiting global warming to $2^{\circ} \mathrm{C}$. Nature, 517 , pp. 187-190.

Mitchell, J., Morita, K. Selley, N., and Stern, J., 2001. The new economy of oil: Impacts on businesses, geopolitics and society. London: Earthscan.

Neumann, C. and Neumann, I. B., 2015. Uses of the self: Two ways of thinking about scholarly situatedness and method. Millennium: Journal of International Studies, 43, 3, pp. 798-819.

Newberry, D., 2013. Energy affects. Proximity and distance in the production of expert knowledge about biofuel sustainability. In: S. Strauss, S. Rupp, and T. Love, eds., Cultures of energy: Power, practices and technologies. Walnut Creek: Left Coast Press, pp. 227-241.

Nilsson, A. and Filimonova, N., 2013. Russian interests in oil and gas resources in the Barents Sea. Stockholm Environment Institute Working Paper 2013: 5. Stockholm Environment Institute. 
Norgaard, K. M., 2011. Living in denial: Climate change, emotions and everyday Life. Cambridge, MA: MIT Press.

Norwegian Ministry of Foreign Affairs, 2014. Norway's Arctic policy. Available at: https://www. regjeringen.no/globalassets/departementene/ud/ vedlegg/nord/nordkloden_en.pdf(Accessed 12 May 2016).

Nymand Larsen, J. and Fondahl, G., eds., 2015. Arctic human development report: Regional processes and global linkages. Akureyri: Stefansson Arctic Institute.

OPEC, 2016. OPEC annual statistical bulletin. Available at: http://www.opec.org/opec_web/ static_files_project/media/downloads/publications/ ASB2016pdf (Accessed 28 April 2016).

PAME, 2009. Arctic marine shipping assessment 2009. Available at: www.pmel.noaa.gov/arctic-zone/detect/ documents/AMSA_2009_Report_2nd_print.pdf (Accessed 10 October 2016).

Palonen, K., 1983. Politics as a dramatic action situation. In: I. Heiskanen and S. Hänninen, eds., Exploring the basis of politics: Five essays on the politics of experience, language, knowledge and history. Tampere: The Finnish Political Association, pp.15-33.

Potter, R. A., 2007. Arctic spectacles: The frozen north in visual culture, 1818-1875. Seattle: University of Washington Press.

Prime Minister's Office of Finland, 2013. Finland's strategy for the Arctic region. Available at: http://vnk. fi/julkaisut/julkaisusarja/julkaisu/en.jsp?oid=395580 (Accessed 20 November 2014).

Psaridikou, K. and Szerszynski, B., 2012. Growing the social: Alternative agrofood networks and social sustainability in the urban ethical foodscape. Sustainability: Science, Practice and Policy, 8, 1, pp. 30-39.

Rasmussen, R. O. and Roto, J., eds., 2011. Megatrends. Copenhagen: Nordic Council of Ministers.

Redclift, M., 2009. The environment and carbon dependence: Landscapes of sustainability and materiality. Current Sociology, 57, 3, pp. 369-387.
Rothbauer, P. M., 2008. Triangulation. In L. M. Given, ed., The SAGE encyclopedia of qualitative research methods. Thousand Oaks: Sage, pp. 893-894.

Rose, G., 2007. Visual methodologies: An introduction to researching with visual materials. London: Sage.

Russian Federation Policy for the Arctic 2020, 2009. Unofficial English translation. Available at: http://www.iecca.ru/en/legislation/strategies/ item/99-thedevelopment-strategyof-the-arcticzone-of-the-russian-federation (Accessed 20 October 2014).

Rüdiger, M., 2008. Introduction. In M. Rüdiger, ed., Culture of energy. Newcastle: Cambridge Scholars Publishing, pp. vii-X.

Salazar Pérez, M. and Cannella, G. S., 2013. Situational analysis as an avenue for critical qualitative research: Mapping post-Katrina New Orleans. Qualitative Inquiry, 19, 7, pp. 505-517.

Salminen, A. and Vadén, T., 2013. Energia ja kokemus: Naftologinen essee. [Energy and experience: A naftologic essay]. Tampere: Eurooppalaisen filosofian seura ry.

Scrase, J. I. and Ockwell, D. G., 2010. The role of discourse and linguistic framing effects in sustaining high carbon energy policy: An accessible introduction. Energy Policy, 38, 5, pp. 2225-2233.

Sengers, F, Raven, R. P. J. M., and Van Venrooij, A., 2010. From riches to rags: Biofuels, media discourses and resistance to sustainable energy technologies. Energy Policy, 38, 9, pp. 5013-5027.

Seppänen, J., 2005. Visuaalinen kulttuuri: teoriaa ja metodeja mediakuvan tulkitsijalle. [Visual culture: Theory and methods for readers of media images]. Tampere: Vastapaino.

Sidortsov, R., 2016. A perfect moment during imperfect times: Arctic energy research in a lowcarbon era. Energy Research \& Social Science, 16, pp. 1-7.

Stammler, F. and Wilson, E., 2016. Beyond extractivism and alternative cosmologies: Arctic communities and extractive industries in uncertain times. The Extractive Industries and Society, 3, pp. 1-8. 
Strauss, S., Rupp, S., and Love, T., 2013. Powerlines. Cultures of energy in the twenty-first century. In: S. Strauss, S. Rupp, and T. Love, eds., Cultures of energy: Power, practices and technologies. Walnut Creek: Left Coast Press, pp. 10-38.

Sørnes, J., Browning L. D., and Henriksen, J. T., 2015. Introduction. In: J. Sørnes, L. D. Browning, and J. T. Henriksen, eds., Culture, development and petroleum: An ethnography of the High North. London: Routledge, 1-12.

Tennberg, M. and Lempinen, H., 2015. Sosiaalista kestävyyttä etsimässä: tapaustutkimuksena Salla. [In search of social sustainability: The case study of Salla, Finland]. Kosmopolis, 45, 3, pp. 27-43.

Tennberg, M. and Vola, J., 2014. Myrskyjä ei voi hallita: Haavoittuvuuden poliittinen talous. [Storms cannot be controlled: The political economy of vulnerability]. Alue ja ympäristö, 43, 1, pp. 73-84.

Tennberg, M., Riabova, L., and Espiritu, A. A., 2012. Introduction to politics of development in the Barents region. In: M. Tennberg, ed., Politics of development in the Barents region. Rovaniemi: Lapland University Press, pp. 16-29.

Tynkkynen, V. and Tynkkynen, N., forthcoming. Climate denial revisited: (Re)contextualising Russian public discourse on climate change during Putin 2.0. Europe-Asia Studies.
Tynkkynen, V., 2016. Energy as power: Gazprom, gas infrastructure and geo-governmentality in Putin's Russia. Slavic Review, 75, 2, pp. 374-395.

USGS, 2009. Assessment of undiscovered petroleum resources of the Barents Sea shelf. United States geological survey fact sheet. Available at: http://pubs. usgs.gov/fs/2009/3037/pdf/FS09-3037.pdf (Accessed 5 August 2017).

Van Leeuwen, T. 2011. Multimodality and multimodal research. In: E. Margolis and L. Pauwels, eds., The SAGE handbook of visual research methods. Thousand Oaks: Sage, pp. 549-569.

Wilson Rowe, E., 2016. The unbuilt environments of Arctic offshore oil and gas development. Hot Spots, Cultural Anthropology website, 29 July 2016. Available at: https://culanth.org/fieldsights/933-theunbuilt-environments-ofarctic-offshore-oil-andgasdevelopment (Accessed 20 August 2016).

Windisch, U., 2008. Daily political communication and argumentation in direct democracy: Advocates and opponents of nuclear energy. Discourse and Society, 19, 1, pp. 85-98.

Wright, T., 2011. Press photography and visual rhetoric. In: E. Margolis and L. Pauwels, eds., The SAGE handbook of visual research methods. Thousand Oaks: Sage, pp. 317- 336. 
